\title{
Higher Agricultural Universities Serve for "Sannong" by Offering English Human Resources Support System
}

\author{
Youqin Yuan \\ Tianjin Agricultural College, Tianjin 300384, China \\ Tel: 86-22-2378-9023 E-mail: cfxyy@126.com \\ Baole Cheng \\ Tianjin Agricultural College, Tianjin 300384, China \\ Tel: 86-22-2378-9023 E-mail: cfxyy@126.com
}

This paper is the research result of "Tianjin Undergraduate Education Reform and the Building of Quality Research Project". Item code: B02-0502

\begin{abstract}
This paper puts higher agricultural English education how to serve for "Sannong" construction as priority, combining the actual market demand, based on teaching reform in the past few years, tries to explore English nurturing model and curriculum system for real delivery the agriculture-related qualified foreign language professionals. The purpose is to improve agriculture-related quality of personnel, expand the Sannong development as well as to reform the Agricultural Universities English subject training objectives, and explore new ways in the solutions on Sannong issues.

Keywords: Sannong, Specialized English, Curriculum System

As we all know that English is the main language of international relations, and is the working language in the United Nations, major international organizations as well as various international academic units. Most of the world's science and technology information is recorded in English. As China's reform and opening up continually deepen the development of inter-cultural exchanges and rapidly expand the scope. Especially after joining the WTO, with the rapid development of economic globalization, China's increasing openness of the international, and information industries to gradually push forward all aspects of life and society. Therefore, the demand for foreign language professionals will be more urgent, the demand for English increased significantly, and the quality of talent on the diversified demands. All of this creates social environment to English-speaking professionals and the basis of social needs, but also to the English professional development provided a good opportunity. In recent years various training institutions, private schools and even foreign universities all enter China, and it is a good trend for domestic foreign language rapid development to improve the level of English language education. Therefore, English diversity education and research is essential.
\end{abstract}

\section{The Statement of Domestic Development}

\subsection{English education convergence and uniformity}

At present, some more developed cities in China has been widely recognized that the importance of English has created a comprehensive learning English atmosphere. But we must also recognize that the convergence and uniformity of the current English education results in narrower performance in the practice has been very prominent. Particularly agriculture and rural economic development fields, the English expertise is also relatively small. Main reasons are, first, English professional institutions set up a relatively late, and have not formed the advantages and features, and the English convergence is lack of "agriculture" characteristics, and other institutions of graduates unable to meet this field. Therefore, as for agricultural universities really face with opportunities and challenges. So agricultural institutions only constant innovation, and establish characteristics English education, create its own brand of subject to seek survival and development, to meet the economic and social purposes. At domestic, there are many good quality research results on English as a purely knowledge, such as English education, linguistics, literature and translation, and other specialized English as a foreign language and literature research fruits. But English plus marketing needs research has only just begun, especially agriculture and English cross study do not have much precedent.

\section{2 "Sannong” and the Specialized English Development}


"Sannong" has been listed as the most important task for the whole party. Development of the rural economy will need a large number of English professional expertise, and the reality is that in China agriculture has been lack of English talent, and this has provided us with opportunities. However, indeed, we must also see that the training zone "agricultural" character English expertise is a kind of innovation, no more experience that we can draw on. Therefore, agricultural universities should be based on the existing prominent foundation to construct characteristic English professional, and training is not only containing solid English professional knowledge, but strong knowledge of agriculture talents to meet rural economic and social development needs. However, the exploration and study on agricultural higher foreign language education how to serve in "Sannong" development has just started, and the results of studies in this area also minimal. The database showed that only "The Thinking on English Professional education reform in Agricultural Universities"(Yuan Youqin 2006). "Foreign Language Training Mode of agricultural universities" (Sun Zhanghai 2006), and other papers make a few of observations on agricultural reform institutions English professional.

\subsection{The Specialized Trend of Higher Education Services Function}

Specialized Institutions of English subject direction is in accordance with the service of field settings. For example, the Medical College English (English medical direction) specialized related to the establishment of the three issues: updated concept of higher education; second, to reform the English education system curriculum goals; Third is English (English medical direction) subject positioning. Therefore, "Strengthening English, understand profession, Broad range as school characteristics. And set up a backbone courses in Economics and Management institutions positioning professional disciplines: English and economic subjects two majors, and English and management two majors go together. Specialized English in Engineering Institutions: (Business English Language and Literature direction together). Training Objectives: To nurture ethics, intellect, physical comprehensive development, and possess theoretical basis of English, and adapt to the 21 st century needs and can working as compound highly qualified personnel in economic, trade, foreign invested enterprises, tourism, culture, and education teaching and translation work. Main courses might be advanced English, senior English writing, English-Chinese Translation, and Foreign Trade English Communication, the International Trade Practice (English version), Business Negotiations (English version), Marketing (English version), English / Literary History and the United States to choose, second foreign language, etc.. Therefore, As an Agricultural College, English subject should be the characteristics with "agriculture" then it may have its own space for development.

\section{The Statement of foreign country's development}

From the point of view of human resources development and management, some researches in the field have been developed more than 60-70 years in some developed countries of the world and a lot of experiences and lessons. Have been accumulated and developed a modern agriculture for qualified human capital. From the development course of abroad is through the first realization of modernization to promote urbanization, and final solve the income issue of peasants. American economist Schulz's "human capital" theory states that through the investment of human resource to form capital. The manpower investment mainly refers to education investment, health care investment, labour mobility investment. On the whole, workers need have a certain labor knowledge, skills and capabilities, thereby creating value and the value of human capital to become the engine of economic development. It is not only the first time formed a clear human capital theory, and further did the quantitative research on the rate of return of investment in education and education role in economic growth. He expounded on the agricultural education: "There is no world-class farmers, there will be no world-class agriculture. Knowledge is the power of agricultural modernization." Relying on his theory in the 20th century, our country has clearly put forward that China's economic construction should transfer the track to scientific and technological progress and improve the quality of laborers in 1980s. In 1990s formed a strategic thinking of "technology rejuvenation" and "developing agriculture through science and technology", clearly reveals that modern agricultural education is the basis of the development of the agricultural economy.

However, Sannong issue is the development planning put forward by our government in recent years with the actual situation of China. The views of Ministry of Education on Higher Agricultural Education services for "Sannong" has just introduced in 2007. Specialized English is a special product in English as a second language country. Particularly under the background of the service for "Sannong", the training model and English curriculum reform study in the agriculture-related institutions has no precedent. Some data indicate that there is no research results in this field abroad that we can draw on, so we must rely on our own research power, in light of China's national conditions, to explore a viable English personnel training system service to serve for "Sannong" construction.

Foreign language teaching theories have not been unable to solve for us the answer to the question, in particular China University English education is the foundation of English teaching in the world is rare. We have to own a Chinese research environment, the characteristics of the transition period in English teaching mode.

\section{The Goal and Course System of serving "Sannong” of English Education in Higher Agricultural University}


3.1 Improve agriculture-related quality of personnel, expand the way of "Sannong" development

3.2 Reform the agricultural university English personnel training objective is an another new way to solve the "Sannong"problems

\subsection{Take the advantages agriculture-related English education in Agriculture University}

3.3.1 Opportunities of serving for "Sannong" provided by transition period characteristics in University College English teaching

1) Basic English teaching is facing transition

As Graddol (2006:15) predicted: "The time of English just as a foreign language to learn is coming to the end." Many scholars have been questioned for unlimited laying foundation in many universities. Gu Bing (2004) pointed out that the University should be compressed public English learning time. Hu Geng-shen (1998) pointed out "if we still use the old teaching model, in the limited hours continued to 'lay a solid foundation', it is bound to lag behind the needs of the community. Cheng Yumen (2002) and Zhangzhenbang (2003) sated that secondary school graduates after entering university should directly transfer to specialized English learning rather learn common English. Language Learning and Knowledge Learning combining together has become a trend in after- college English time.

2) "A thousand people one face" teaching methods just transferring to the variety teaching

3) Curriculum Requirements need of reform

The Curriculum Requirements is not in line with the talent diverse needs under the condition of market economy. The study recommends that college English 4, 6 and TEM 4 and 8 exam, after completing its historic task should change their role timely, set to be a level of examination. That is to say that rather than test the students if they achieve Curriculum Requirements to the general standard of English level integrated application capability, and to the services providing to employing units. Thus, the economic university can do to economic characteristics, agricultural universities to highlight the "agricultural" character.

3.3.2 Rational utilization of higher education resources, and reform of specialized English training model to meet the needs of English in agriculture

This study suggests that reasonable use of education resources in agricultural university, and reform English training model to form a system of English language + relative subject curriculum. Compress ratio and proportion of credits in language foundation courses, and the overall teaching model is divided into six modules: Module I of general education courses, II language professionals basic course module, III specialized direction of basic education modules, IV language specialized modules, V specialized direction modules, VI specialized practice teaching modules.

3.3.3 Agricultural colleges teaching pre-reform achieved initial success

The English professional placement rate of graduates of more than 80 per cent, most students working in agriculture, the farmers, farm producing fields, foreign invested enterprises, and agriculture units employment and most of them got laudatory comments by the agriculture-related employing units.

3.3.4 English subject positioning to the University should be channel to foreign language education for easier characteristic curriculum system development

English subject positioning attributable to the foreign language education instead of foreign language and literature, it may firstly give university English teachers higher demands in the knowledge structure. And they must learn foreign language education theory. If the English as a branch of foreign language pedagogy, it is in favor of the comprehensive universities to improve the quality of English teachers, to be conducive to the students English application ability. This is the question having to be considered in transition periods for nurturing characteristic talents.

\section{References}

College Foreign Language Teaching English Group Steering Committee. (2000). College English professional English syllabus. Foreign Language Teaching and Research Press. P.102.

Department of the People's Daily. (2006). New rural construction concise Reading. Beijing: Red Flag Publishing House.

Dr Yu. (2006). Future. TIANJIN: Tianjin People's Publishing House.

Gui Shichun. (2004). China's foreign language education in the fundamental way. China Foreign Language, Foreign Language Teaching and Research Press, 10- 13.

Hu Zhuanglin. (2002). On China's English Education of thinking. Foreign language Studies. (3).

Cai, JiGang. (2007). Transition period of China's college English teaching characteristics and countermeasures research. Language Teaching and Research Press. 
Zhang, KeLiang. (2000). Technology from the English practice of the reform of the training of personnel of foreign language. Journal of the People's Liberation Army Institute of Foreign Languages, (9).

Luo, Ping. (2000). Also on the 21st century composite Foreign Language Training mode. Language Sector, (3).

Shuho. (2002). English Professional Training System of Innovation Research and Practice. Foreign language teaching, $6,52-55$.

Wang, GuangZhong. (2005). Higher Agricultural Reform and Development of Innovative Explorations. Beijing: China Agriculture Publishing House. P.32. 